\title{
Identity in Shakespeare
}

\author{
Jay L. Halio \\ University of Delaware \\ jl.halio@yahoo.com
}

\begin{abstract}
This paper surveys the problems of identity in a number of Shakespeare's plays, such as The Taming of the Shrew, The Comedy of Errors, As You Like It, Twelfth Night, The Merchant of Venice, Romeo and Juliet, Hamlet, and Othello. In these plays as in many others, Shakespeare explores the complexity of identity, not only through the use of disguise, as in the major comedies, but also through the problems of self-knowledge. The latter issue is prominent and explicit in King Lear when, for example, Lear asks "Who is it that can tell me who I am?" The opening words of Hamlet, "Who's there?" introduce the problem from the outset, and much of the play is given over to characters trying to discover who the others in the play really are. Is the Ghost an honest ghost, or "a goblin damned?" Is Hamlet really mad or just putting on an "antic disposition" as he struggles to discover his proper course of action as his father's avenger? Is Kate really a shrew, or just made to act like one by her family and others?
\end{abstract}

In act 1 , scene 4 , King Lear asks:

Does anyone here know me? This is not Lear.

Does Lear walk thus? speak thus? Where are his eyes?

Either his notion weakens, his discernings

Are lethargied - Ha! waking? 'Tis not so. 
He concludes, "Who is it that can tell me who I am?" The question is pertinent and gets the answer from the Fool: "Lear's shadow."

This occurs near the beginning of Lear's awakening, his long journey, like many of Shakespeare's protagonists, to self-discovery (Jorgenson: 1967).En route, gradually but forcibly losing his self-centeredness, he becomes aware of others. In the storm scenes, for example, he begins to take pity on his poor shivering Fool, who has tried to get him to take some shelter. He also begins to realize what kind of king he has been, pondering the plight of the "Poor naked wretches" of whom he has failed to take proper care (3.4). But before he confesses to Cordelia that he is "a very foolish fond old man" (4.7), he must endure the fiery crucible of madness, which burns away many of the delusions he has hitherto entertained about himself, his family, and his kingdom.

Lear's learning experience is extreme, but not all of Shakespeare's protagonists go through quite the same route to self-knowledge. Questions of identity, not only in tragedy, seem to have preoccupied Shakespeare from very early in his career. While in The Comedy of Errors, one of his first plays, he borrowed his plot from Plautus's Menaechmi, he further complicated his version by adding a second set of twins, confusing all the characters on stage and, at times - depending on how it is stagedeven the audience. The confusions are of course hilarious; but meanwhile the two Antipholi learn a great deal about themselves and those closest to them. Antipholus of Ephesus, for example, learns what a true and loving wife he has, despite all the abuse he feels he has endured. On her part Adriana confesses that, regardless of all she has suffered during the confusions, she still loves her husband deeply. ${ }^{2}$

I have argued elsewhere that the Induction to The Taming of the Shrew provides important clues as to what exactly is going on in the main action (Halio: 2002). Christopher Sly is made to believe that he is someone he really is not, and once persuaded, he behaves accordingly. I believe this indicates very significantly how we should understand Katherina's behavior. Regarded by everyone as a shrew and treated accordingly, she acts the part so convincingly that none of the eligible bachelors in Padua will have anything to do with her. Katherina's tongue spits out venom indiscriminately; she goes so far as to tie up and beat her sister Bianca in act 2, scene 1 so that she certainly appears to be a shrew. But is she?

Enter Petruchio, who at first refuses to acknowledge Kate's reputation. He treats her very differently from everyone else, insisting that she is "the prettiest Kate in Christendom," "my super-dainty Kate," and so on. He says that:

Hearing thy mildness prais'd in every town,

Thy virtues spoke of, and thy beauty sounded,

Yet not so deeply as to thee belongs,

Myself am mov'd to woo thee for my wife.

(2.1.191-4)

Katherina can hardly believe what she hears and begins verbally abusing him. Nothing daunted, Petruchio perseveres, determined to reveal the true woman underlying the 
persona Katherina has been schooled in, not least by her father, who wants nothing better than to get her off his hands so that Bianca can also get married.

Although at first Katherina stoutly refuses to marry Petruchio and vigorously repels his overtures, when it comes down to it, she is dressed and ready for the wedding. And when Petruchio fails to appear on time, she is genuinely distressed. Later, when he takes her to his home, she finally becomes aware of what her husband is up to and understands what her proper role is. She obeys his every command, even kissing him in the public thoroughfare, and at the closing banquet lectures the other brides on why and how wives should behave. No one should miss the point that Shakespeare makes about Katherina's true identity.

Shakespeare makes his female characters assume male attire to pursue their worthy aims. Of course, everyone recognizes that boys played women's roles, and it was partly for this reason, perhaps, that Shakespeare resorted to disguising his heroines. But does not this resort also suggest that Shakespeare responded to what he recognized as feminine wit and cleverness? In As You Like It Rosalind, banished by Duke Frederick, heads to the Forest of Arden dressed as a man. She jokes with Celia about her disguise, as women will, but her disguise turns out to be much handier to her than she supposed when she encounters Orlando in the forest. In her own person could she have tutored him so well in what it means to fall in love and get married? Could Portia in The Merchant of Venice be nearly so successful in helping Antonio had she not assumed the disguise as Dr. Balthazar? False identity, then, has its positive advantages in some circumstances, though not all.

These positive advantages, if not always immediately apparent, are shown in Twelfth Night. Shipwrecked on the shores of Illyria - wherever that happens to beViola learns of Olivia and Orsino from the captain who helped to save her. She decides to seek service with the Countess, but hearing that that is not possible, she determines instead to assume a disguise and serve the duke. Why? She says that her disguise "haply shall become / The form of my intent" (1.2.55). What "intent" is that? Does she from the outset set her cap for the duke? All she says is:

I can sing

And speak to him in many sorts of music

That will allow me very worth his service.

What else may hap, to time I will commit....

$(1.2 .57-60)$

And so she assumes the name of Cesario, a eunuch, and within three days wins the favor of Orsino, as Valentine says (1.4.1-4).

Of course, Viola quickly falls in love with her master, but ironically he uses her as a go-between to press his suit to Olivia. Shakespeare compounds the irony when Olivia falls madly in love with Viola as Cesario. Viola is astonished when she realizes this and comments wittily on her predicament when Malvolio brings her the ring Olivia sends: 
What means this lady?

Fortune forbid my outside have not charm'd her!

She made good view of me; indeed so much

That methought her eyes had lost her tongue,

For she did speak in starts distractedly.

She loves me sure, the cunning of her passion

Invites me in this churlish messenger.

None of my lord's ring? Why, he sent her none.

I am the man! If it be so, as 'tis,

Poor lady, she were better love a dream.

Disguise, I see thou art a wickedness

Wherein the pregnant enemy does much.

How easy is it for the proper-false

In women's waxen hearts to set their forms!

Alas, [our] frailty is the cause, not we,

For such as we are made [of,] such we be.

How will this fadge? My master loves her dearly,

And I (poor monster) fond as much on him;

And she (mistaken) seems to dote on me.

What will become of this? As I am a man,

My state is desperate for my master's love;

As I am a woman (now alas the day!),

What thriftless sighs shall poor Olivia breathe!

O time, thou must untangle this, not I,

It is too hard a knot for me t' untie.

$(2.2 \cdot 17-41)$

Time does untangle this, though it takes rather longer than the way Time untangled the confusions in The Comedy of Errors. It does so when Viola's twin, her brother Sebastian, appears on the scene. He had not drowned after all! Lest we think Shakespeare is here using a deus ex machina illegitimately, remember that the Captain told Viola in 1.2 that he last saw her brother tied to a mast "that liv'd upon the sea," sporting upon the waves like Arion on the dolphin's back (1.2.11-17). Time may bring its revenges, as Feste says (5.1.376-7), but it also brings its rewards.

Rewards for what? For Viola's courage and loyalty? They almost backfire when Orsino realizes that Olivia has fallen for Viola in her disguise as his man, Cesario. Furious, he proclaims that though he "tenders [Cesario] dearly":

Him will I tear out of that cruel eye,

Where he sits crowned in his master's spite.

Come, boy, with me, my thoughts are ripe in mischief.

I'll sacrifice the lamb that I do love,

To spite a raven's heart within a dove.

(127-31)

Viola's response reveals her loyalty to Orsino in extraordinary terms: 
And I most jocund, apt, and willingly,

To do you rest, a thousand deaths would die.

$(132-3)$

The revelations of true identity do not invariably end well in this play, as we see from what happens to Malvolio. Tricked into believing that his fondest wishes have been realized, the puritanical steward woos Olivia in a scene whose farce and pathetic aspects are not entirely absent. The Countess understandably thinks Malvolio is a victim of "midsummer madness" (3.4.56) and orders her people to look after him with "a special care" (60-2). They do, but probably not in the way Olivia expects, even though putting a person mad or possessed into a dark chamber was not unusual treatment in Elizabethan times. Malvolio, of course, is not really mad, but seriously put upon by Maria, Sir Toby, and the others. His treatment in the dark room under Feste masquerading as the curate Sir Topas is both hilarious and cruel. Hence, when he is finally released and the trick that set him off is disclosed, it is no wonder that he does not join in the joke and cries, "I'll be revenged on the whole pack of you" (5.1.378). As Olivia says, "He hath been most notoriously abus'd" (379).

Prince Hal in Henry IV, Part 1, seems to enjoy his reputation as the scapegrace Prince of Wales, and in his important soliloquy in act 1, scene 2, he tells the audience why he is consorting with Falstaff and his cronies:

I know you all, and for a while uphold

The unyok'd humor of your idleness.

Yet herein will I imitate the sun,

Who doth permit the base contagious clouds

To smother up his beauty from the world,

That when he please again to be himself,

Being wanted, he may be more wondr'ed at

By breaking through the foul and ugly mists

Of vapors that did seem to strangle him.

If all the year were playing holidays,

To sport would be as tedious as to work;

But when they seldom come, they wish'd for come,

And nothing pleaseth but rare accidents.

So when this loose behavior I throw off

And pay the debt I never promiséd,

By how much better than my word I am,

By so much shall I falsify men's hopes,

And like a bright metal on a sullen ground,

My reformation, glitt'ring o'er my fault,

Shall show more goodly and attract more eyes

Than that which hath no foil to set it off.

I'll so offend, to make offense a skill,

Redeeming time when men think least I will. (1.2.195-217) 
Some commentators have a problem with this speech, as it reveals Prince Hal as a manipulative, not to say conniving, individual, using friends in a most unbecoming fashion. They see him as the true scion of King Henry who, by his early return from exile, won the crown partly by deceiving others into believing that he was only coming to claim his heritage as Duke of Lancaster, not to deprive King Richard II of his throne. As events in the Battle of Shrewsbury show (act 5, scene 3), Henry is not above using other deceptions, as when he has a number of his knights dressed in his "coats." These pseudo-kings befuddle the Scot Douglas, who thinks he has won the battle by killing Sir Walter Blunt so attired (5.3.16-25). Be that as it may, the true characters of both Henry and Hal reveal themselves eventually, their deceptions having done what they were intended to do.

Identity in Romeo and Juliet becomes problematical in another way, especially when Romeo overhears Juliet's soliloquy:

\section{Romeo, Romeo, wherefore art thou Romeo? \\ Deny thy father and refuse thy name; \\ Or if thou wilt not, be but sworn my love, \\ And I'll no longer be a Capulet.}

$(2.2 .33-6)$

Juliet is intelligent enough to recognize the difference between nominal and actual identity, as she says: "Tis but thy name that is my enemy;/ Thou art thyself, though not a Montague." (38-9). Romeo is who and what he is, regardless of his family identity conveyed by his surname. Nevertheless, this is a difficult issue for Romeo to deal with; he is not nearly as smart as Juliet. "Call me but love," he responds, "and I'll be new baptiz'd, / Henceforth I never will be Romeo" (50-1). His name is hateful to himself, he says, because it is an enemy to her. But Juliet is much more concerned at this moment with Romeo's safety, barely hidden as he is beneath her balcony. She is far more pragmatic than her romantic suitor, who utters hyperboles and metaphors while she tries to figure out how he got where he is and what might happen to him if he is discovered. And then she cuts to the chase: "Dost thou love me?" (90). Convinced of his seriousness, after some further love talk between them, she puts it to him:

If that thy bent of love be honorable,

Thy purpose marriage, send me word tomorrow,

By one that I'll procure to come to thee,

Where and what time thou wilt perform the rite,

And all my fortunes at thy foot I'll lay,

And follow thee my lord throughout the world.

(143-8)

So much for names, which began their dialogue. The essentials, who they are as individuals, and the quality of their love, are now firmly established between themselves, though not among the rest of their family and friends, except for Friar 
Lawrence. And this failure of identification leads inexorably to their tragedy. Hamlet is full of the mystery of identity from the very opening lines of the play onwards:

Barnardo Who's there?

Francisco Nay, answer me. Stand an unfold yourself.

As Stephen Booth and others have shown, the challenge is reversed: it is Francisco, the guard on duty who is about to be relieved, who should challenge Barnardo (Booth: 1969). But this is just preliminary to the more important problem of identity that occupies the first half of the play: the nature of the Ghost. What kind of ghost is it that has stalked the ramparts of Elsinore Castle two nights running? Or is it merely a fantasy, as Horatio thinks (1.1.23)? Horatio's skepticism is quickly countered by the Ghost's appearance. But why the Ghost has appeared he fails to discover, since the Ghost refuses to reply to his questions. It is left for Hamlet, whom Horatio and Marcellus inform, to try to uncover the answers.

Hamlet is only partly successful. The Ghost appears before him in such "questionable shape" (1.4.43) that he cannot at first determine whether it is "a spirit of health, or a goblin damn'd" (1.4.40). After hearing the Ghost's story, Hamlet's initial belief is that "It is an honest ghost," as he tells Horatio (1.5.138), but for the next two months the Ghost's ambiguity and his charge to revenge puzzle Hamlet. Meanwhile, Hamlet assumes an "antic disposition" (1.5.172) to disguise his sanity and win time to sort things out. Only after he stages "The Murder of Gonzago" does he feel he has enough evidence to confirm the Ghost's account of his father's murder. But almost simultaneously he kills the wrong man in a rash, impulsive effort to take revenge.

The entire second act, in fact, is fraught with disguise and false identities. Claudius summons Rosencrantz and Guildenstern, Hamlet's schoolmates at Wittenburg, to try to pluck the heart out of the mystery of his strange behavior. Hamlet, however, swiftly uncovers the reason for their sudden appearance in Elsinore and warns them that he is "but mad north-north-west" (2.2.378). Ophelia, too, has been brought into her father's and Claudius's intrigue and made to act as a decoy in the Nunnery Scene to help prove Polonius's theory regarding Hamlet's assumed madness. Again, Hamlet penetrates this intrigue and, because he feels betrayed by her, treats his quondam sweetheart as a whore. Earlier, as she tells her father at the beginning of act 2, he had appeared in Ophelia's closet as a distracted lover, an act that provides Polonius with his theory of Hamlet's love sickness.

The central issue in the play, however, apart from all these ancillary questions of identity, concerns Hamlet's role, or his identity, as an avenger. Literary tradition, and indeed the source of the Hamlet myth in Saxo Grammaticus, held that, in the absence of justice meted out to the murderer, it became incumbent upon a father's son to exact revenge. The lex talionis had to be brought to bear: an eye for an eye, a tooth for a tooth, a murder for a murder. But unlike his precursors, Hamlet does not "sweep" to his revenge (cp. 1.5.26). His hesitation to act against Claudius — his long delay — has been 
explained by many as the result of a number of causes including, most famously (or notoriously) the debilitating effects of an oedipal complex.

These various theories purporting to explain Hamlet's delay overlook what seems to me of the utmost importance: that Shakespeare did not conceive of his Hamlet ${ }^{3}$ as a typical avenger, clearly not in the mode of Hieronimo in Kyd's Spanish Tragedy or Hoffman or Antonio in other earlier Elizabethan revenge tragedies. Hence, Shakespeare was careful to frame the Ghost's charge thus:

Let not the royal bed of Denmark be

A couch for luxury and damnéd incest.

But howsomever thou pursues this act,

Taint not thy mind, nor let thy soul contrive

Against thy mother aught. Leave her to heaven. . . .

$(1.5 .82-6)$

The third line in this passage is key: the Ghost leaves it up to Hamlet to figure out the way to exact revenge. But what kind of revenge? Though twice before he has called for revenge, nowhere does the Ghost actually say "Kill Claudius!" He seems primarily interested in stopping the moral pollution of an incestuous union between his brother and his wife. And he commands Hamlet to do this without becoming morally tainted himself, and without proceeding through Gertrude.

Of course, killing Claudius would be the way most of Shakespeare's audience would expect Hamlet to take revenge. And at a crucial moment Hamlet almost does just that. In act 3, scene 3, finding Claudius alone, he draws his sword to dispatch the king, who is on his knees in an attitude of prayer. But unwilling to kill his uncle while in a state of grace, this diabolically motivated Hamlet sheathes his sword, hoping to kill him later when he is "about some act / That has no relish of salvation in't" (3.3.91-2). In so doing, Hamlet nearly damns himself and proceeds immediately in the next scene to kill Polonius. From that point, having violated one of the Ghost's negative injunctions "Taint not thy mind" - Hamlet begins to shrive his mother, urging her to repent, and thereby violating the Ghost's second negative injunction.

The Ghost's final appearance doubtless prevents Hamlet from attacking Gertrude with more than words and signals the beginning of the Prince's character transformation. Calmer now, he soon recognizes his fault in killing Polonius:

For this same lord,

I do repent; but heaven hath pleas'd it so

To punish me with this, and this with me,

That I must be their scourge and minister.

"Scourge and minister"? Surely the two roles are antipathetical, one to the other, as Shakespeare must have realized when he came to write King Lear. In that play, as Virgil Whitaker long ago noted, he divided the roles between Goneril, Regan, and 
Edmund - the scourges - and Cordelia and Edgar — the ministers (Whitaker: 1965). Trying to be both scourge and minister is perhaps Hamlet's main difficulty. Though in his last soliloquy he berates himself - "How all occasions do inform against me, / And spur my dull revenge" - and ends with "O from this time forth, / My thoughts be bloody or be nothing worth" (4.4.32-2, 65-6), when he returns from his aborted trip to England he has no plan for taking action against Claudius. On the contrary, he seems resigned to let providence direct his course. And it does. ${ }^{4}$

In his next tragedy Shakespeare again focuses on the issue of identity, though without all the complications that Hamlet provides. For starters, Othello enjoys the reputation of being the best soldier in Venice, the general assigned to lead the battle against the Turks, who threaten to invade without, and these involve the identity of Iago. Enjoying the reputation of "Honest Iago," the villain is not by any means Cyprus. But by act 3, things begin to change. The Turkish threat appears to have been a kind of red herring; worse threats lie within, since he is not what he appears to be. As he declares to Roderigo in the opening scene, "I am not what I am" (1.1.65). It takes the rest of the play's action for Othello to discover just what he is. By that time, Othello's own identity has changed completely.

Privileged to know Iago intimately, as we the audience do, thanks to his soliloquies as well as his dialogue with Roderigo, how should we credit what he says about reputation to Cassio in act 2? After disgracing himself in his fight with Montano, Cassio laments the loss of his reputation:

Reputation, reputation, reputation! O, I have lost my reputation! I have lost the immortal part of myself, and what remains is bestial. My reputation, Iago, my reputation!

$(2.3 .262-5)$

Iago immediately pooh-poohs Cassio's concern:

Reputation is an idle and most false imposition; oft got without merit, and lost without deserving. You have lost no reputation at all, unless you repute yourself the loser.

$(268-71)$

Reputation, as Cassio conceives of it, is directly related to one's identity, to how others see us and recognize us for who and what we are. But Iago dismisses this idea, claiming that one's own sense of self is what is important. He takes the opposite view when speaking with Othello early in the seduction scene:

Good name in man and woman, dear my lord,

Is the immediate jewel of their souls.

Who steals my purse steals trash; 'tis something, nothing; 
'Twas mine, 'tis his, and has been slave to thousands;

But he that filches from me my good name

Robs me of that which not enriches him,

And makes me poor indeed. (3.3.155-61)

Before their dialogue is concluded, not only has Desdemona's reputation, or identity, been ruined in Othello's eyes, but his own as well:

O now, for ever

Farewell the tranquil mind! farewell content!

Farewell the pluméd troops and the big wars

That makes ambition virtue! O, farewell!

Farewell! Othello's occupation's gone.

Othello's mistake has been in too closely identifying himself with his love for Desdemona which, when that is gone, so is his former identity as the great general that he once was. Or, to put it another way: by placing Desdemona on so high a pedestal as he does - that the merest shadow of a doubt about her true identity may bring her down - he brings himself down with her. Reputation, or rather one's conception of oneself, one's self-identity, as Iago counsels Cassio, should be made of sterner stuff than that and not tied to another's.

In Macbeth Duncan mourns the thane of Cawdor's treason, summarily sentences him to death, and bestows his title on Macbeth (1.2.63-6). When Malcolm tells him how Cawdor died, Duncan replies:

There's no art

To find the mind's construction in the face.

He was a gentleman on whom I built

An absolute trust.

(1.4. 11-14)

Duncan here articulates a significant truth that Shakespeare had touched on earlier in The Merchant of Venice. When Bassanio approaches the three caskets, he rejects the gold and silver ones, saying, "So may the outward shows be least themselves./ The world is still deceiv'd by fair ornament." Duncan, deceived as he was by Cawdor, builds a similar trust on Macbeth, only to be deceived much worse by him. Macbeth's betrayal succeeds, as Cawdor's did not, though only briefly. After murdering his king, kinsman, and guest, Macbeth undergoes a transformation of character quite unlike Hamlet's or Othello's. From "Bellona's bridegroom" (1.2.54) his identity changes; he becomes a murderous, tyrannical usurper, fooled by the witches' equivocating words, his wife's boundless ambition, and his futile quest for ironclad security.

Lady Macbeth also changes. Once a self-assured, resourceful woman, her invocation to the spirits of evil to "unsex" her, to thicken her blood and "Stop up th' access to remorse" in herself (1.5.40-44) succeeds only too well, at least at first. She manipulates 
her husband into taking "the nearest way" to the crown they both evidently covet (1.5.16-21); but once it is achieved she is helpless to stop Macbeth from pursuing the kind of security he desperately desires. She dies a poor, pathetic psychotic, the victim of as powerful a conscience or imagination as Macbeth's, no longer either the strong, resourceful woman she was at the beginning, or the bloody, "unsexed" murderer she strove to become.

Antony's reputation as a "triple pillar of the world" is questioned at the outset of the tragedy in which he is the protagonist along with Cleopatra. What Philo refers to as his general's "dotage," Antony sees as a boundless love that can only be reckoned by finding out "new heaven, new earth" (1.1.17-18).

\section{Notes}

1. So in the Folio version. In the Quarto, Lear provides the answer himself.

2. See, for example, the dialogue with her sister in 4.2.1-28.

3. Evidently, there was an earlier play, the so-called Ur-Hamlet, sometimes attributed to Kyd, but long since lost.

4. See his dialogue with Horatio, 5.2.210-24. Of course, Hamlet's revenge ultimately costs him his own life as well as Claudius's, perhaps the price he pays for wishing Claudius damned and killing Polonius. See the discussion above.

\section{References}

Booth, Stephen (1969): “On the Value of Hamlet". In Norman Rabkin, ed., Reinterpretations of Elizabethan Drama. New York: Columbia University Press, 137-76.

Halio, Jay L. (2002): "Induction as Clue to The Taming of the Shrew". In L. Anderson and J. Lull Newark, eds., A Certain Text: Essays on Shakespeare and Others in Honor of Thomas Clayton. Delaware: University of Delaware Press, 94-106.

Jorgenson, Paul (1967): Lear's Self-Discovery. Berkeley: University of California Press. Whitaker, Virgil (1965): The Mirror up to Nature: The Technique of Shakespeare's Tragedies. San Marino: Huntington Library, 216-18. 